\title{
弾性壁間の狭いすき閒内における粘性流体の自由表面の挙動 The motion of free surface of viscous fluid in narrow gap between elastic walls
}

\author{
$\bigcirc$ 宗高 大和（長岡技科大） \\ 正古口 日出男（長岡技科大） \\ Yamato MUNETAKA, Nagaoka University of Technology,1603-1 Kamitomioka, Nagaoka, Niigata \\ Hideo KOGUCHI, Nagaoka University of Technology,1603-1 Kamitomioka, Nagaoka, Niigata
}

Key Words: Meniscus Instability, Elastic Sheet, Newtonian Fluid, Squeeze Flow

\section{1. 緒言}

2 枚の平行な板の狭いすき間に粘性流体を満たし，上側 の板を一定速度で引き離すと，負圧によって空気がすき間 に入り込み, 流体の残留液膜が板面上に複雑な樹枝状パタ ーンを形成する場合がある。これはメニスカス不安定現象 と呼ばれ, 接着テープの剥離面やすべり軸受内の破断油膜, 非晶質材料の引張破断面などにおいても観察される.

既往の研究では，流体を挟む平板は圧力による変形が無 視できる剛体板とみなされていた。しかし，濡れた路面と ゴムタイヤの接触や動物の関節内部など，より一般的には 流体を挟む物体の変形を考慮する必要があると思われる. そこで，本研究では流体を挟む平板に弾性シートを貼り付 け，圧力による弾性変形を考慮した場合のメニスカス不安 定現象を調べる。特に, 本報では自由表面上の摂動の成長 条件を解析的に導出し，実験結果と比較する.

\section{2. 理論解析}

$2 \cdot 1$ 圧力の基本解

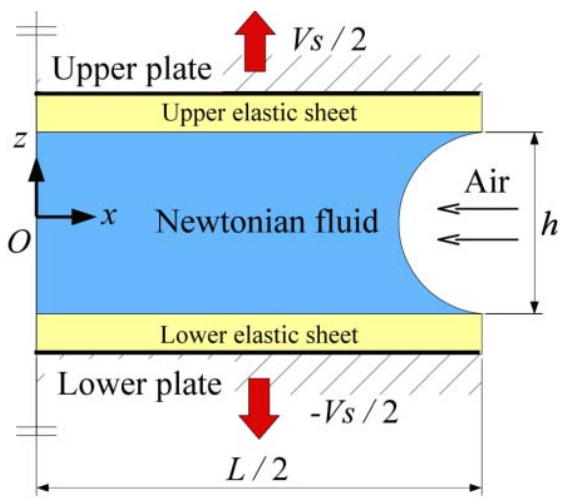

Fig.1 Schematic image of the analysis model

図 1 に解析モデルを示す. 粘度 $\mu$ の非圧縮性ニュートン 流体が長さ $L$, 幅 $B$ の平板のすき間 $h$ （初期すき間 $h_{0}$ ）に 挟まれている。平板の上下には弾性定数と厚さがそれぞれ $E_{u}, E_{l}, d_{u}, d_{l}$ の弾性シートが接着されている。座標原点 を液膜の左端に取り，板の長さ方向を $x$ 軸，幅（奥行き） 方向の $y$ 軸, 厚さ方向を $z$ 軸とする.

まず，圧力の基本解を求める。 引き離し速度を $V_{s}$, 圧力 を $p$, 表面張力を $\sigma$ とする. 基礎式は次の Reynolds 方程式で ある。

$$
\frac{\partial}{\partial x}\left(h^{3} \frac{\partial p}{\partial x}\right)+A^{2} \frac{\partial}{\partial y}\left(h^{3} \frac{\partial p}{\partial y}\right)=12 C a^{\circ}
$$

ただし, $A=L / B$ であり, 各変数は以下のように無次元化 される。

$$
x=\frac{x^{*}}{L}, y=\frac{y^{*}}{B}, z=\frac{z^{*}}{h_{0}}, t=\frac{V_{s} t}{h_{0}}, h=\frac{h^{*}}{h_{0}}, p=\frac{p^{*}}{\sigma / L}
$$

また, 式(1)右辺の無次元数は修正キャピラリ数であり, 次 式で表される.

$$
C a^{\circ}=\frac{\mu V_{s}}{\sigma}\left(\frac{L}{h_{0}}\right)^{3}
$$

いま, $A \rightarrow 0$ として $y$ 方向に圧力が変化しないものとする このときの圧力 $p_{0}$ をとおき, 境界条件

$$
\left.\frac{d p_{0}}{d x}\right|_{x=0}=0 \quad p\left(x_{s}\right)=-\frac{2 \beta}{h_{B}}
$$

の下で解くと, 圧力の基本解が次のように求まる.

$$
p_{0}(x)=\frac{1}{\alpha}\left[\left\{24 \alpha C a^{\circ}\left(x^{2}-x_{s}^{2}\right)+h_{B}^{4}\right\}^{\frac{1}{4}}+H\right]
$$

ここで, $x_{s}$ は自由表面までの平均距離, $\beta=L / h_{0}, H=1+t$ であり，

$$
h_{B}=\frac{H+\sqrt{H^{2}-8 \alpha \beta}}{2} \quad \alpha=\frac{\sigma}{h_{0} L}\left(\frac{d_{u}}{E_{u}}+\frac{d_{l}}{E_{l}}\right)
$$

である。

\section{$2 \cdot 2$ 摂動解析}

次に摂動の成長条件を求める。自由表面上のy方向に微

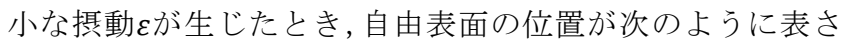
れたとする。

$$
\begin{gathered}
X\left(x_{s}, y, t\right)=x_{s}(t)+\varepsilon e^{\omega t} \cos (k y / A) \\
\text { これに応じて圧力も次のように変化したとする. } \\
\quad p(x, y, t)=p_{0}(x)+\varepsilon G(x) e^{\omega t} \cos (k y / A)
\end{gathered}
$$

ここで, $\omega$ は摂動の成長速度， $k$ は摂動の波数である. 摂動 項 $G(x)$ は式(8)を式(1)に代入して得られる次の微分方程式 から求められる.

$$
\frac{d^{2} G}{d x^{2}}+\frac{3}{h} \frac{d h}{d x} \frac{d G}{d x}-k^{2} G=0
$$

式(9)は求積法では解けないので, 摂動展開による 1 次近似 解を求める. 式(9)の解が $G \approx G_{0}+\alpha G_{1}$ と表されるとし, こ れを代入すると,

$$
\begin{aligned}
& G_{0}^{\prime \prime}-k^{2} G_{0}=0 \\
& G_{1}^{\prime \prime}-k^{2} G_{1}=-q(x) G_{0}^{\prime} \\
& q(x)=\frac{36 C a^{\circ} x}{24 \alpha C a^{\circ}\left(x^{2}-x_{s}^{2}\right)+h_{B}^{4}} \\
& \text { これらを解くと, } \\
& G_{0}=C_{1} e^{k x}+C_{2} e^{-k x} \\
& G_{1}=C_{3} e^{k x}+C_{4} e^{-k x}+g_{1} \\
& g_{1}=-\frac{e^{k x}}{2 k} \int e^{-k x} q(x) G_{0}^{\prime} d x \\
& \quad+\frac{e^{-k x}}{2 k} \int e^{k x} q(x) G_{0}^{\prime} d x
\end{aligned}
$$

$C_{1}$ から $C_{4}$ までの未定係数は次の境界条件から求める.

$$
G\left(x_{s}\right)=k^{2}-\left.\left.\frac{d p_{0}}{d x}\right|_{x=x_{s}} \quad \frac{d G}{d x}\right|_{x=0}=0
$$

次に $\omega に$ 関する関係式を導く.式(7)を時間で微分すると 界面の移動速度が求まる。また, 式(13)で与えられる平均 流速の式に界面の位置を代入しても界面の速度が求まる。

$$
\overline{v_{x}}=-\frac{h^{2}}{12 C a^{\circ}}\left(\frac{d p_{0}}{d x}+\frac{d G}{d x} \varepsilon e^{\omega t} \cos (k y / A)\right)
$$

これらの式を比較し, $\varepsilon$ の 1 次の項をまとめると, 次式が得 られる。 


$$
\omega=-\left.\frac{1}{12 C a^{\circ}}\left(\frac{24 \alpha C a^{\circ} x_{s}}{h_{B}^{2}} \frac{d p_{0}}{d x}+h_{B}^{2} \frac{d G}{d x}\right)\right|_{x=x_{s}}
$$

摂動が成長するためには $\omega$ が正でなければならない。した がって，次式が摂動の成長条件である。

$$
\left.\frac{d G}{d x}\right|_{x=x_{s}}<-\frac{\left(24 C a^{\circ} x_{s}\right)^{2} \alpha}{2 h_{B}^{7}}
$$

また，摂動が成長するときには，摂動の成長速度 $\omega$ が最大 になる場合が観察されると思われる。そこで，式(14)を波 数で微分して 0 とおくと, 次式を得る.

$$
\frac{d}{d k}\left(\left.\frac{d G}{d x}\right|_{x=x_{s}}\right)=0
$$

弾性変形を考慮しない場合, 式(15)および式(16)に対応する 関係式は次の通りである。

$$
\begin{aligned}
& C a^{\circ}>\frac{H^{3}}{12 x_{s}} k^{2} \\
& C a^{\circ}=\frac{H^{3}}{12 x_{s}} k^{2}\left(\frac{3}{x_{s}}-\frac{4 k}{2 k x_{s}+\sinh \left(2 k x_{s}\right)}\right)
\end{aligned}
$$

簡単のために,ここでは, 時間がほとんど経過しておらず, 自由表面がほとんど移動していない場合, 寸なわち, $t=0$, $x_{s}=0.5$ の場合を考える. 理論的な摂動波長は式(15)および 式(16)を波数あるいは波長に関する非線形方程式として数 值的に解くことで求められる.

\section{3. 実験}

\section{3・1 実験方法}

実験は以下のように行った。 $L=30 \mathrm{~mm}, B=100 \mathrm{~mm}$, $E=0.83 \mathrm{MPa}, d=3 \mathrm{~mm}$ の弾性シート(ハイパーゲル 3030T, (株)エクシールコーポレーション) を 2 枚, 平行に対向さ せた上下の基板に接着し，その間に粘度 $\mu=9.75 \mathrm{~Pa} \mathrm{~s}$, 表面 張力係数 $\sigma=21.3 \mathrm{mN} / \mathrm{m}$ のシリコーンオイル $(\mathrm{KF}-961$ 万 $\mathrm{cSt}$, (株)信越シリコーン) を入れる。 その後, 引張試験機を用 いて上側の板を一定速度で引き離し，このときの自由表面 の移動を下側に設置したミラーを通してビデオカメラで撮 影する。そして, 得られた画像から摂動成長の初期段階に おける波長を測定する．表 1 に実験条件を示す．実験は各 条件で 3 回ずつ行い, その平均波長を求めた。また，同じ 寸法のアクリル板に対しても同一の実験条件で実験を行っ た.

\section{$3 \cdot 2$ 実験結果}

図 2 に各初期すき間に対する修正キャピラリ数と摂動波 長の関係を示す．赤色のマーカーは弾性シート，青色のマ 一カーはアクリル板の各条件における実験結果を示してい る. 青色の点線と赤色の白抜き○はそれぞれ平板と弾性シ 一トにおける摂動の成長速度を最大にする波数の条件（式 (16)および式(18)），青色の一点鎖線と赤色の白抜き $\square$ はそ れぞれ摂動の成長条件（式(15)および式(17)）である.

図 2 より，実験で観測される摂動の波長はすべて式(15) および式(18)の成長条件を満たす不安定領域にあることが わかる.また，キャピラリ数が小さいときには最大成長速 度の条件に近い波長が観測されることがわかる。しかし， キャピラリ数が大きくなるにつれて，観測される波長は各 初期すき間に応じた一定值に近づく傾向にある。これは残 留液膜の影響であると考えられる。理論解析ではすき間方 向の流速分布や残留液膜などを考慮していないため, この ような傾向は見られない。

弾性シートと平板の波長の理論值にはほとんど差がない. これは今回の実験条件では変形の度合いを示すパラメータ $\alpha$ が $10^{-6}$ 程度であり，弾性変形による効果がほとんど現れ
なかったためである。今後は弾性シートの支持方法を変え るなど変形量が大きくなるような実験を行い，また，残留 液膜やすき間方向の流れを考慮した解析を行う必要がある と思われる。

\section{4. 結言}

弾性シートを有する平行平板間のメニスカス不安定現象 について, 線形安定性理論に基づき, 修正キャピラリ数と 摂動波長の関係式を導出した。また，弾性シートと平板の 両方について同一の条件で波長計測実験を行い，それぞれ を比較・検討した.

\section{参考文献}

(1)古口，岡田，機論（B 編）， 53-491 (1987), 2062.

(2)古口，田村，矢田，機論（B 編）， 54-505 (1988), 2446.

Table.1 Experiment condition

\begin{tabular}{|l|c|}
\hline$h_{0}, \mathrm{~mm}$ & $0.3,0.5,0.75,1.0$ \\
\hline$V_{S}, \mathrm{~mm} / \mathrm{min}$ & $0.5,1,2,5,10,20,50,100$ \\
\hline
\end{tabular}

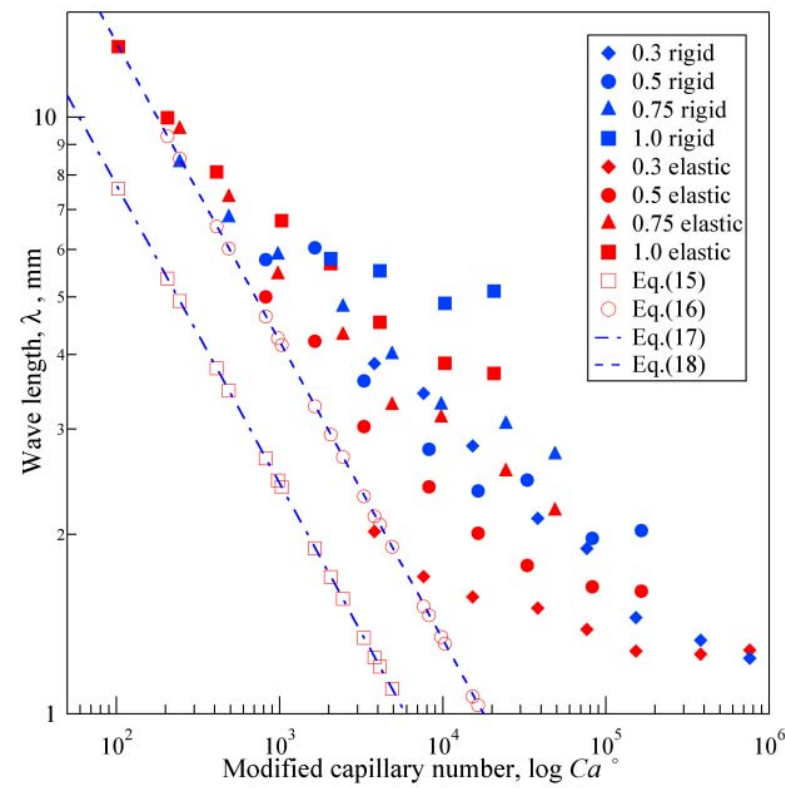

Fig.2 Relationship between modified capillary number and wave length 